Prace Filologiczne. Literaturoznawstwo 10(13) 2020

ISSN 2084-6045

e-ISSN 2658-2503

Creative Commons: Uznanie autorstwa 3.0 PL (CC BY)

DOI: $10.32798 /$ pflit.580

\title{
PREKURSORZY RYMKIEWICZA*
}

\section{Rymkiewicz's Predecessors}

\author{
JAN POTKAŃSKI \\ Uniwersytet Warszawski, Polska \\ E-mail: jan2@go2.pl \\ ORCID: 0000-0002-9332-1940
}

\begin{abstract}
The article describes how the historical essays of Jarosław Marek Rymkiewicz depend on the works of his important predecessors. This dependency is analysed in accordance with Harold Bloom's "anxiety of influence" theory. I bring up well-known sources, such as the works of Maria Janion, less-remembered sources, such as the essays of Jerzy Łojek, as well as sources that may initially come as a surprise, such as the philosophy and biography of Michel Foucault. In interpreting these connections I develop Bloom's psychoanalytical inspirations, but I also problematise them by juxtaposing them with the "schizoanalysis" proposed by Gilles Deleuze and Félix Guattari in Anti-Oedipus.
\end{abstract}

Keywords: Jarosław Marek Rymkiewicz, Michel Foucault, Harold Bloom, psychoanalysis, anxiety of influence

\section{Streszczenie}

Artykuł opisuje zależność historycznych esejów Jarosława Marka Rymkiewicza od twórczości znaczących dla pisarza poprzedników, analizowaną zgodnie z Harolda Blooma teorią „lęku przed wpływem”. Obok źródeł oczywistych, takich jak dzieła Marii Janion, wskazane są tu również te słabiej pamiętane, jak eseistyka Jerzego Łojka, a także zaskakujące zrazu, jak filozofia i biografia Michela Foucaulta. Interpretacja tych związków rozwija psychoanalityczne inspiracje Blooma, problematyzując je wszakże zestawieniem ze „schizoanalizą” zaproponowaną w Anty-Edypie Gillesa Deleuze'a i Félixa Guattariego.

Słowa kluczowe: Jarosław Marek Rymkiewicz, Michel Foucault, Harold Bloom, psychoanaliza, lęk przed wpływem

*Publikacja artykułu dofinansowana przez Uniwersytet Warszawski. 
1.

Spekulując na temat wyglądu tytułowego bohatera, Jarosław Marek Rymkiewicz kwestionuje w Samuelu Zborowskim wiarygodność dostępnej ikonografii, proponując w zamian - bez żadnych podstaw źródłowych - wizję konkurencyjną: Samuela z głową i twarzą w pełni ogoloną. Nie objaśnia jej sensu, jawnie łączy jednak ten typ wyglądu $\mathrm{z}$ własnym, podkreślając, że sam tak właśnie się goli ${ }^{1}$. Tym samym sylleptycznie splata postać bohatera z lustrzanym odbiciem siebie jako autora, co esej historyczny czyni alegorycznie autotematycznym.

Jak rozumieć ten gest? Eseista po części zapewne identyfikuje się ze swoim bohaterem, czując się podobnym do niego nonkonformistą, nie posuwa się jednak do porównania własnych kłopotów z literacko-politycznym salonem i „męczeństwem" (bo tak ujmuje jego śmierć) Samuela. Struktura całego porównania groziłaby zresztą w takim przypadku samoośmieszeniem - skoro wizualne tertium comparationis (ogolona czaszka) to tylko fantazja eseisty, zbyt pochlebny dla autora sens moralny takiego zestawienia paralelnie demaskowałby się jako megalomania. Do kogo więc faktycznie mógłby się w tym miejscu porównywać Rymkiewicz, skoro bezpośrednie z pozoru zestawienie ze Zborowskim przy bliższym rozważeniu okazuje się dysonansem domagającym się rozwiązania? Moim zdaniem - do Michela Foucaulta, którego taka właśnie wygolona czaszka trwale zapisała się w ikonografii dwudziestowiecznej humanistyki.

Sama analogia wizualna to oczywiście za mało, żeby uznać francuskiego filozofa za ukryty w wyobrażeniu Zborowskiego właściwy merytorycznie comparans. Takie zestawienie wspierają jednak poboczne analogie rozsiane po tekście Samuela Zborowskiego i pozostałych książkach z „tetralogii polskiej”. W Samuelu Rymkiewicz delektuje się opisami kaźni ${ }^{2}$ - co bardzo przypomina początek Nadzorować $i$ karać $^{3}$. Zacytowana tam przez Foucaulta narracja przedstawia egzekucję królobójcy - a królobójstwo to temat, wokół którego Zborowski ciągle krąży, w odmiennym kontekście podejmując wątek z Wieszania. W całej tetralogii (najmocniej jednak w Kinderszenen i Reytanie) ${ }^{4}$ Rymkiewicz afirmuje patriotyczne szaleństwo, nawet jeśli wiedzie ono do wzniosłej samozagłady. Ta jest jednak postrzegana jako coś lepszego niż polityczny „rozsądek” mierzący zamiary podług sił, który zdaniem poety prowadzi Polaków ku wynarodowieniu. Rymkiewiczowska pochwała szaleństwa odzwierciedla antypsychiatryczne wątki

1 „Ja, tym samym prawem, którym malarz Matejko domalował mu rozłożystą czarną brodę, zabieram mu brodę, wąsy i każdy włos z głowy, nawet szarawą resztkę włosów, która mogłaby, z boków i z tyłu, otaczać łysinę. Zostawiam gołą czaszkę, gładko wygoloną (jak moja, jak moja!), białą, trochę widmową"; J. M. Rymkiewicz, Samuel Zborowski, Warszawa 2010, s. 63.

${ }^{2}$ Ibidem, s. 9-11, 82-85.

${ }^{3}$ M. Foucault, Nadzorować i karać, tłum. T. Komendant, Warszawa 1998, s. 7-9.

${ }^{4}$ J. M. Rymkiewicz, Kinderszenen, Warszawa 2008, s. 185-192; J. M. Rymkiewicz, Reytan. Upadek Polski, Warszawa 2013, s. 87-89. 
myśli Foucaulta, które filozof rozwija w książkach Choroba umysłowa a psychologia i Historia szaleństwa $w$ dobie klasycyzmu. Rymkiewicz chce, aby w jego eseistyce i poezji represjonowane patriotyczne szaleństwo Polaków doszło do głosu tak samo, jak Foucault chciał do niego dopuścić zniewolonych szaleńców w przedmowie do Histoire de la folie. Jednak znamieniem Zborowskiego staje się nie dosłownie rozumiane szaleństwo, lecz porównawczo przywołany przez Foucaulta jego strukturalny odpowiednik w kulturze antycznej - hybris ${ }^{5}$.

Obok analogii z Rymkiewiczem, Foucaulta łączy też coś z samym jego bohaterem - to właśnie, czego Rymkiewiczowi brakuje, mianowicie „męczeństwo". W mitologii queer theory śmierć filozofa na AIDS, przedstawiana jako nie przypadkowa, lecz przeciwnie - świadomie wybrana (przez niezaniechanie ryzykownych kontaktów seksualnych w czasie, gdy niebezpieczeństwo zarażenia HIV było już znane), funkcjonuje właśnie jako rodzaj męczeństwa wyrażającego - mówiąc językiem Lacana z Etyki psychoanalizy - wierność swojemu pragnieniu. W przypadku Foucaulta wyraża ono subwersywną seksualność ale generuje taką samą strukturę jak bardziej konwencjonalnie tragiczne religijne pragnienie Antygony u Lacana, by pochować brata, i pragnienie warszawskich powstańców, by ruszyć na wroga, choćby militarnie straszliwa klęska była nieunikniona. Antygona, Foucault i powstańcy w kluczowym momencie znajdują się „pomiędzy dwiema śmierciami” - w interwale między świadomym narażeniem się na śmierć a faktycznym jej nadejściem - i zgodnie z tezą Lacana jaśnieją w nim nadludzkim pięknem ${ }^{7}$. Samuel Zborowski u Rymkiewicza przedstawiony jest tak samo - jako „przepych” we wzniosłym czasie pomiędzy rzuceniem wyzwania Zamoyskiemu a egzekucją.

Wizualne zestawienie się Rymkiewicza z Foucaultem w Samuelu Zborowskim sugeruje, że istnieje jakiś rodzaj personalnej relacji z francuskim pierwowzorem, podobnej trochę do lustrzanej identyfikacji ze wzorcem, którą postuluje Lacan jako kluczowy etap rozwoju osobowości ${ }^{8}$. Moje ujęcie tego stosunku wykracza więc poza standardowe wskazanie analogii materiału literackiego i propozycji filozoficznych, które dla relacji Rymkiewicz-Foucault badali Dorota Wojda ${ }^{9}$,

${ }^{5}$ M. Foucault, Przedmowa, tłum. T. Komendant, w: M. Foucault, Powiedziane, napisane. Szaleństwo i literatura, Warszawa 1999, s. 5-14. Co istotne dla zestawienia z Rymkiewiczem, Foucault na koniec zaznacza, że jego praca była „kończona pod wielkim upartym słońcem polskiej wolności” i że ,przyjaciele polscy [wiedza]], że coś z ich obecności pozostało na tych stronicach”.

${ }^{6}$ Np. D. M. Halperin, Saint Foucault. Towards a Gay Hagiography, New York 1995.

${ }^{7}$ Cf. J. Lacan, The Ethics of Psychoanalysis 1959-1960, trans. D. Potter, New York 1992, s. $243-287$.

${ }^{8}$ J. Lacan, Stadium zwierciadta jako czynnik ksztattujący funkcję Ja, w świetle doświadczenia psychoanalitycznego, tłum. J. W. Aleksandrowicz, „Psychoterapia” 1997, nr 4, s. 5-9.

${ }^{9}$ Np. D. Wojda, Rewizje historii i dyskursu kryminologicznego: Kuśniewicz, Terlecki, Rymkiewicz, „Przestrzenie Teorii” 2011, nr 15, s. 169, 172. 
Dominik Chwolik ${ }^{10}$ i Olga Masiuk ${ }^{11}$. Joanna Dembińska-Pawelec zestawia tymczasem Rymkiewicza z Haroldem Bloomem ${ }^{12}$, sugerując, że zarówno przedstawiona w Czym jest klasycyzm? teoria, jak i opisywane przez Rymkiewicza jako badacza i eseistę relacje między poetami przypominają te omawiane przez autora Lęku przed wpływem. Zastanawiając się nad relacją samego Rymkiewicza z prekursorami, Dembińska-Pawelec przywołuje Mickiewicza. W ogólności nie jest to jednak przykład będący w duchu teorii Blooma, skoro autor Żmutu darzy wieszcza jawnym kultem, a nie skrycie z nim rywalizuje, pragnąc się od wpływu uwolnić. Bardziej przekonujący w kontekście Blooma wydaje się Gombrowicz, którego poeta sam wskazuje jako tego, z którego wpływem walczył ${ }^{13}$. Niemniej w specyficznym kontekście Samuela Zborowskiego i rola Mickiewicza się zmienia, bo Rymkiewicz stawia się poniekąd na miejscu poprzednika w kulcie Samuela, Juliusza Słowackiego ${ }^{14}$ - a ten już niewątpliwie z Mickiewiczem rywalizował i może nawet wpisał ten agon w relację Zborowskiego z Zamoyskim w swoim dramacie ${ }^{15}$. Takie przesunięcie identyfikacji mogłoby skądinąd tłumaczyć, dlaczego w książce Zamoyski jest antypolskim zbrodniarzem, podczas gdy nieco wcześniej, w wywiadach - wybitnym polskim politykiem ${ }^{16}$. Czy ten bardzo heterogeniczny na pierwszy rzut oka zbiór - Mickiewicz, Gombrowicz, Foucault - da się zsyntetyzować w jednolitego prekursora Rymkiewicza (Bloom dopuszcza takie syntezy ${ }^{17}$ ?

Przezwyciężywszy wstępną niechęć, późny Gombrowicz identyfikuje się ze strukturalizmem, do którego zaliczano wtedy Foucaulta; w Dzienniku wprost wymienia go jako autora Les mots et les choses $^{18}$. Mickiewicza z Foucaultem łączy jedno tertium comparationis oczywiste: wykłady w Collège de France. Ale z obecnością Mickiewicza w Paryżu rezonuje też praca Foucaulta na Uniwersytecie Warszawskim i potem jego przyjazd do Warszawy z pomocą dla

${ }^{10}$ D. Chwolik, Rymkiewicz. Dopowiedzenia, Katowice 2016, s. 120-127.

${ }^{11}$ O. Masiuk, Mickiewiczowski „tekst życia” w eseistyce Jarostawa Marka Rymkiewicza. Lektura biografii romantycznego poety w cyklu „Jak bajeczne żurawie”, https://depotuw.ceon.pl/ handle/item/1937 (d.d. 11.03.2019).

12 J. Dembińska-Pawelec, Upiorna wersja tradycji czy romans rodzinny. Rymkiewicz i Bloom paralela, „Śląskie Studia Polonistyczne” 2013, nr 1, s. 281-295.

${ }^{13}$ Ibidem, s. 289.

${ }^{14}$ Cf. A. Czajkowska, Wpływ bez lęku. Jarosław Marek Rymkiewicz czyta Juliusza Stowackiego, „Wiek XIX. Rocznik Towarzystwa Literackiego im. A. Mickiewicza” 2009, R. 2, s. 160-173.

${ }^{15}$ Cf. M. Kuziak, „Samuel Zborowski”. Rymkiewicz w zwierciadle Stowackiego, ,Ruch Literacki” 2013, nr 4-5, s. 495-516.

${ }^{16}$ J. M. Rymkiewicz, Rozmowy polskie w latach 1995-2008, Warszawa 2009, s. 142, 192 (wywiady z lat 2006-2007).

${ }^{17}$ H. Bloom, Lęk przed wptywem. Teoria poezji, tłum. A. Bielik-Robson, M. Szuster, Kraków 2002, s. 55.

${ }^{18}$ W. Gombrowicz, Dziennik 1961-1969, Kraków 2004, s. 231; cf. s. 244-246 (Foucaultowskie pojęcie episteme). 
represjonowanej „Solidarności” (który stanowi jakby dopełnienie wstrzymanej wyprawy wieszcza ku powstaniu listopadowemu $)^{19}$. W standardowym ujęciu ironiczna polskość Gombrowicza przeciwstawia się romantyczno-mesjańskiej Mickiewicza $^{20}$. Współcześnie pisarz odtworzył niejako tę relację $\mathrm{w}$ sporze z Czesławem Miłoszem, wprost na dziedzica wieszcza się stylizującym ${ }^{21}$, a i chyba przez Rymkiewicza przyjętym $\mathrm{w}$ tej roli $^{22}$. Z punktu widzenia lacanizmu ta skomplikowana sieć związków i analogii (metonimii i metafor) reprezentuje przejście od prostego lustrzanego utożsamienia z prekursorem (wizerunkiem wygolonego Foucaulta) do identyfikacji symbolicznej, zapośredniczonej w systemie signifiants.

Zebrane w spójne „ciało” znaczące mają one zdaniem Lacana fantazmatycznie tworzyć Wielkiego Innego. Dla Rymkiewicza jego ostateczną postacią jest polski duch jako język (zwłaszcza poetycki) i kultura wzmocnione jakąś mistyczną domieszką. Ten Wielki Inny staje jednak do konfrontacji z innym: Francją i jej kulturą, zarówno filozoficzną, jak i polityczną. Reprezentacją jej polityczno-kulturowej jedności był tradycyjnie monarcha. Tymczasem Wieszanie i Samuel Zborowski paralelnie podejmują kwestię królobójstwa. Podwojenie tego rodzaju sugeruje, że jest to dla Rymkiewicza kwestia szczególnie istotna. Nie może więc być przypadkiem, że dwakroć wzorem dla Polaków miałoby być królobójstwo francuskie. W Wieszaniu jawnie - warszawiacy mieliby powiesić Stanisława Augusta tak, jak paryżanie ścięli Ludwika XVI. W Samuelu osobliwiej - Rymkiewicz fantazjuje o zabiciu Henryka Walezego przez jednego $\mathrm{z}$ jego polskich poddanych ${ }^{23}$, nie wspomina jednak, że faktycznie został on zabity - tyle że jako Henryk III, król Francji - przez francuskiego mnicha. Czytana z perspektywy Lacana historia pokazuje, że zabicie króla bynajmniej nie oznacza wymazania królewskiej suwerenności - raczej przeciwnie, to właśnie te $\mathrm{z}$ europejskich państw, które zdobyły się na egzekucję króla (Anglia i Francja), wydają się symbolicznie najbardziej suwerenne. Ojciec (w opisywanej już przez Freuda hiperboli - król) wkracza dla Lacana w rolę symboliczną właśnie jako martwy. Rymkiewicz nie waha się sugerować, że właśnie takiego suwerennego zabójstwa Polakom w historii zabrakło, mimo że stoi to w sprzeczności z paralelnie ponawianymi zapewnieniami, że są oni narodem szczególnie wspaniałym (jest to rodzaj „podwójnego wiązania” w rozumieniu

${ }^{19}$ D. Eribon, Michel Foucault. Biografia, tłum. J. Levin, Warszawa 2005, s. 123-127, 369-378.

${ }^{20}$ Np. S. Chwin, „Trans-Atlantyk” wobec „Pana Tadeusza”, „Pamiętnik Literacki” 1975, nr 4, s. $97-121$.

${ }^{21}$ Cf. M. Delaperrière, Dialog Miłosza z Mickiewiczem, „Postscriptum Polonistyczne” 2011, nr 1, s. 233-246.

${ }^{22}$ J. Dembińska-Pawelec, Jarostaw Marek Rymkiewicz w cieniu Miłosza, „Ruch Literacki” 2012, nr 2, s. 209-226.

${ }^{23}$ J. M. Rymkiewicz, Samuel Zborowski, s. 27-28. 
Gregory'ego Batesona - oczekiwanie naśladownictwa i oryginalności jednocześnie, tak samo, jak w modelu Blooma) ${ }^{24}$. Ta dwuznaczność przeważnie umyka komentatorom, czytającym Wieszanie jako proste zalecenie królobójstwa ${ }^{25}$. Konstytutywną dla Polaków ambiwalencję w tym zakresie explicite i obszernie zanalizował jednak Rymkiewicz wcześniej, w Wielkim księciu, spekulując, że podchorążowie zarazem chcieli (musieli) i nie chcieli (nie mogli) zabić Konstantego Romanowa ${ }^{26}$.

Struktura „deficytu” narodowej suwerenności Polaków, która nie zdołała utrwalić się królobójstwem, zdaje się u Rymkiewicza paralelna do rozważań Jana Sowy z Fantomowego ciała króla - mimo że Sowa w prosty sposób identyfikuje się z zachodnioeuropejską „normą”, podczas gdy Rymkiewicz próbuje ją zakwestionować (ale też wbrew pozorom nie potrafi jej jednoznacznie odrzucić). Zdaniem Sowy, przedrozbiorowi Polacy byli w strukturalnym Lacanowskim sensie psychotykami, bo nie uwewnętrznili na serio królewskiej suwerenności jako odpowiednika Imienia Ojca w neurotycznej strukturze „normalnej” psychiki - dokonali więc konstytutywnego dla psychozy „wykluczenia”, odmawiając oddania części swojej osobistej wolności na rzecz wspólnotowej suwerenności prawa, a zatem poddania się „kastracji” ${ }^{27}$. Teoria Rymkiewicza jest w zasadzie podobna, odwraca tylko wartościowanie - to wspaniale, że Polacy obronili całość osobistej wolności w konfrontacji z suwerennością państwa. Czy to znaczy, że afirmowane zwłaszcza w Kinderszenen i Reytanie „szaleństwo” patriotycznie nastawionych Polaków można utożsamić z psychozą w sensie psychoanalitycznym? Lacana interesowały raczej struktury „wyższe” niż psychoza, opisuje więc wykluczenie Imienia Ojca głównie jako negatywność, co pasuje do krytycznego spojrzenia Sowy, nie pozwala jednak zrozumieć szczegółów afirmacji ze strony Rymkiewicza. Psychozę samą w sobie pomaga zanalizować raczej Melanie Klein, więc to do jej teorii warto w pierwszym rzędzie przyrównać Samuela Zborowskiego.

${ }^{24}$ Kwestia jednoczesnej polskości i francuskości bądź europejskości insurekcji pojawia się w rozmowie Rymkiewicza z Justyną Sobolewską (2007), rzecz zasadniczo nie wykracza jednak poza prostą konstatację „cudownego” paradoksu; J. M. Rymkiewicz, Rozmowy polskie..., s. $169-170$.

${ }^{25}$ Np. G. Marzec, Hermeneuta i historia. Jarosław Marek Rymkiewicz w Bakecie, Warszawa 2012, s. 41-42: „A teza postawiona w Wieszaniu jest prosta niczym budowa cepa: gdyby rewolucja w 1794 roku nam się udała, gdybyśmy powiesili króla, Polacy staliby się narodem nowoczesnym cokolwiek miałoby to znaczyć. Teza ta, w nieco może łagodniejszej formie, zostaje powtórzona w Samuelu Zborowskim".

${ }^{26}$ J. M. Rymkiewicz, Wielki książe. Z dodaniem rozważań o istocie i przymiotach ducha polskiego, Warszawa 2011, s. 7-33.

${ }^{27}$ J. Sowa, Fantomowe ciało króla. Peryferyjne zmagania z nowoczesna forma, Kraków 2011, s. 403-410. Sowę z Rymkiewiczem zestawia Kuziak, op. cit., s. 512. 
Zgodnie z modelem Klein ${ }^{28}$, psychotyczna faza rozwoju osobowości obejmuje dwa podsystemy: pozycję schizoidalno-paranoidalną i depresyjno-maniakalną. Faza schizoidalna według Klein to z jednej strony radykalne rozszczepienie obiektu (matczynej piersi) na dobry i zły aspekt, z drugiej - radykalny atak na obiekt ujęty jako „zły”, prowadzący do krwawej fragmentacji. U Rymkiewicza najwięcej obrazów tego typu jest w Kinderszenen - „szaleni” Niemcy powodują rozkawałkowanie swoich polskich ofiar, na co warszawscy powstańcy odpowiadają własnym „szaleństwem”. Wojenna pamięć i wyobraźnia Rymkiewicza znajduje tu ścisły paralelizm w wyobrażeniach Klein i jej pacjentów. Antycypują ten wątek obrazy krwawych walk w Warszawie z Wieszania, w tym dionizyjski sparagmos młodego Rosjanina ${ }^{29}$. W Samuelu Zborowskim echem tego fantazmatu są sceny kaźni jako rozczłonkowania, wbudowane są one jednak w bardziej złożoną konstrukcję. Wyobrażony atak na wciąż karmiący obiekt matczyny skutkuje, zdaniem Klein, fantazmatem paranoicznym - że karmiąca matczyna pierś zechce się zemścić. Najprostszą jego realizacją $w$ świecie historycznym jest domniemanie trucicielstwa - że pokarm okaże się zabójczy, jak szkło połykane przez oszalałego z rozpaczy Reytana ${ }^{30}$. Rymkiewicz spekuluje o otruciu zarówno Zygmunta Augusta, jak i Stefana Batorego (podobnie jak we wcześniejszych esejach księcia Konstantego i prymasa Poniatowskiego) $)^{31}$. Konstruuje też jednak bardziej metaforyczne odpowiedniki tej fantazji, według których zagrożeniem dla szlacheckiej złotej wolności miałby się stać sam importowany (niczym zagraniczna trucizna) elekcyjny władca - tak samo Henryk Walezy, jak chwilę potem Stefan Batory - jak i generalnie wszelka zagraniczna ideologia zagrażająca spójności narodowego imaginarium. Diagramatycznie podobny jest motyw czołgu-pułapki, centralny w Kinderszenen. W Foucaultowskiej warstwie Rymkiewiczowskiego fantazmatu zsyntetyzowały się tu może różne etapy życia francuskiego filozofa - dysydenckie idee wsączane polskim mignons (powtarzającym mignons Henryka Walezego) u schyłku lat pięćdziesiątych, za które Foucault został wydalony z UW, z zarazą, której filozof padł ofiarą u progu lat osiemdziesiątych (Bloom porównuje poetycki wpływ do choroby - skoro zaś rodzi się on w miłości do prekursora i jego muzy, prototypowo musiałaby to być choroba weneryczna: u progu nowożytności zapewne syfilis, który Rymkiewicz imputuje Zygmuntowi Augustowi, na przełomie XX i XXI wieku - właśnie AIDS) ${ }^{32}$.

${ }^{28}$ M. Klein, Uwagi na temat niektórych mechanizmów schizoidalnych, thum. A. Czownicka, w: M. Klein, Pisma, t. 3: Zawiść i wdzięczność, Gdańsk 2007, s. 1-25.

${ }^{29}$ J. M. Rymkiewicz, Wieszanie, Warszawa 2007, s. 42-47.

${ }^{30}$ J. M. Rymkiewicz, Reytan..., s. 229-231, 243-244.

${ }^{31}$ J. M. Rymkiewicz, Wieszanie, s. 157; J. M. Rymkiewicz, Samuel Zborowski, s. 164, 238, 264-273; J. M. Rymkiewicz, Wielki książę..., s. 199-204.

${ }^{32}$ A. Bielik-Robson, Sześć dni stworzenia. Harolda Blooma mitologia twórczości, w: H. Bloom, op. cit., s. 209. Cf. S. Sontag, Choroba jako metafora. AIDS i jego metafory, thum. J. Anders, Warszawa 1999. 
Chociaż w Samuelu Zborowskim łatwo rozpoznać logikę fazy schizoidalno-paranoidalnej, nie wydaje się, żeby wyczerpywała ona jego przesłanie. Przedstawiana tam mocarstwowa wspaniałość Polski realizuje raczej ideał maniakalny niekwestionowanej potęgi. Jednak psychoanaliza uznaje manię za semantycznie wtórną względem depresji - maniak czuje się potężny nie sam z siebie, lecz zaprzeczając słabości i upokorzeniu. Trudno takowe przypisać szesnastowiecznej Rzeczypospolitej, choć można by już personalnie Samuelowi Zborowskiemu jako banicie, który brawurą chciał swojemu wygnańczemu statusowi zaprzeczyć (a zasłużył na wygnanie skutkami agresywnej drażliwości, skądinąd także dla manii charakterystycznej). W strukturę depresyjną łatwo natomiast wpisać główny przedmiot zainteresowania Rymkiewicza - polski romantyzm. Porozbiorowi Polacy utracili swój libidalny obiekt - ojczyznę - i wielu z nich (w tym wieszczowie) zostało zmuszonych do przestrzennego zdystansowania się wobec pozostałego po niej terytorialnego „ciała”33 (paralelnie do wyobrażeń rekonstruowanych przez Klein). Ich prototypem w imaginacji Rymkiewicza wspieranej przez dramat Słowackiego łatwo mógł zostać wygnaniec Zborowski, walczący z depresyjnym lękiem skuteczniej niż potem Mickiewicz wobec powstania. Cofnięcie się ku czasom potęgi Rzeczypospolitej byłoby zatem samo w sobie figurą manii jako zaprzeczenia rozbiorowej depresji, paralelną do „krzepienia serc" przez Sienkiewicza. Przejście z depresji w manię jako operację raczej na wyobrażeniach niż realiach bezpośrednio - choć chyba wbrew intencjom autora - przedstawiają po dwakroć Kinderszenen: najpierw w psychice przyszłych powstańców upokorzenie okupacyjną bezsilnością przekształca się w irracjonalną wiarę w zwycięstwo wbrew wszelkiej militarnej logice, potem paralelnie poeta katastrofalną klęskę uznaje za „duchowe zwycięstwo”, nie troszcząc się o podanie jakichkolwiek argumentów ${ }^{34}$. Co do skutków brawura w manii nie różni się jednak od depresyjnego samobójstwa z rozpaczy, którego próbuje Kościuszko, a dokonuje Reytan.

Kluczowa figura w teorii Klein to wszechpotężna matka, od której niemowlę jest w pełni zależne, ale którą postrzega jako śmiertelne zagrożenie. W świecie Wieszania i Reytana postacią taką - choć geograficznie odległą w formie typowej dla depresji, ustanawiającej obronny dystans wobec groźnego obiektu - zdaje się Katarzyna II. W Samuelu Zborowskim nie ma jednoznacznego odpowiednika, są jednak rozproszone ślady takiego fantazmatu: „czarownice” Zygmunta Augusta, Anna Jagiellonka jako wiekiem i urodzeniem (ale nie faktyczną władzą) dominująca nad Stefanem Batorym, „Pani Krakowska” litująca się nad

${ }^{33} \mathrm{O}$ „okropnej depresji” Słowackiego pracującego nad Anhellim vide J. M. Rymkiewicz, Rozmowy polskie..., s. 96.

${ }^{34}$ P. Skwieciński, Książa na nowe czasy, w: Spór o Rymkiewicza, red. T. Rowiński, Warszawa 2012, s. 157. 
zwłokami Samuela, Katarzyna Medycejska jako inicjatorka nocy św. Bartłomieja (Rymkiewicz insynuuje, że syn Katarzyny, Henryk Walezy, analogiczną rzeź protestantów chciał sprowokować w Polsce; zbieżność imion obu potężnych Katarzyn może być istotna z perspektywy mechanizmów nieświadomości). Ani jednak te postaci, ani nawet caryca nie wydają się specjalnie istotne dla Rymkiewicza - zdaje się on wręcz umniejszać ich rolę w stosunku do realiów historycznych. Jego model „szaleństwa” Polaków powtarza więc schemat teorii Gillesa Deleuze'a, który najpierw w szerokim zakresie do Klein nawiązywał (w Logice sensu), by następnie (już we współpracy z Félixem Guattarim w Anty-Edypie) afirmować „schizola” jako „sierotę” wolnego od podległości matce tak samo, jak od edypalnego prawa ojcowskiego. Rymkiewiczowska psychoza jako absolutna wolność jest więc ostatecznie psychozą typu deleuzjańskiego - wolnością od wpływu obojga rodziców, tak ojca („króla”), jak i matki („królowej”). Nie znaczy to oczywiście, że zależność od takich kryptorodzicielskich instancji w ogóle w świecie Rymkiewicza nie występuje. Traktowana jest tam jednak nie jako normalny aspekt rozwoju osobowości, lecz dewiacja charakteryzująca zdrajców (Stanisław August) lub tyranów (Zamoyski) - a zatem, z psychoanalitycznego punktu widzenia, jako perwersja.

Analizując z inspiracji Lacana perwersje w Prezentacji Sacher-Masocha, Deleuze opisuje masochizm jako sojusz z matką przeciwko edypalnemu ojcu, który dzięki seksualnym rytuałom ma zostać wymazany z imaginarium, sadyzm zaś symetrycznie - jako absolutyzację ojca anihilującą matkę ${ }^{35}$. W tym sensie masochistą jest Stanisław August sprzymierzający się z potężniejszą od niego Katarzyną przeciw ojczystemu państwu i prawu, sadystą - Zamoyski dążący do królewskiego absolutyzmu z pogwałceniem „matczynej” troski o życie współobywatela.

Deleuzjański model masochizmu jako matriarchatu kieruje uwagę na kolejną postać z pewnością dla Rymkiewicza istotną - Marię Janion. Jako matriarchalną można interpretować strukturę słynnego gdańskiego seminarium Janion, podobnego w swej kulturowej roli do wykładów Mickiewicza bądź Foucaulta w Collège de France (tudzież do seminarium Lacana). Figurą matriarchatu posługuje się też jednak explicite sama Janion, afirmatywnie rozwijając uwagi Białoszewskiego z Pamiętnika z powstania warszawskiego ${ }^{36}$. To istotne dla zestawienia z Rymkiewiczem, skoro „cywilny” Białoszewski z powstania jest przeciwieństwem walecznych powstańców z Kinderszenen - być może zatem ten esej Rymkiewicza pozostaje do Polskiej prozy cywilnej Janion w takiej samej relacji, co Reytan do rozdziału „Patriota-wariat” z Wobec zła, których związek wychwycił

\footnotetext{
${ }^{35}$ G. Deleuze, Masochism. Coldness and Cruelty, trans. J. McNeill, New York 1989, s. 57-68.

${ }^{36}$ M. Janion, Polska proza cywilna, „Teksty” 1975, nr 2, s. 13-38 (o matriarchacie: s. 23).
} 
niejeden recenzent ${ }^{37}$. Z kolei Przedmowa do transgresji Foucaulta przethumaczona na potrzeby seminarium Janion ${ }^{38}$ wydaje się afirmowanym, a nie polemicznie odwróconym wzorcem Samuela Zborowskiego - Samuel dosłownie (ściśle według wzoru, który z Bataille’a wywiódł Foucault) przekracza zamknięte dla siebie jako banity granice, rzucając wyzwanie prawu, którego egzekutorem mianował się Zamoyski.

Sadystą nazywa Rymkiewicz kilkakrotnie Konstantego Romanowa, m.in. w kontekstach sugerujących, że nie chodzi tylko o potoczną hiperbolę brutalnych zachowań, lecz i stricte o perwersję seksualną, nawet w wątku o osobliwej „miłości” wielkiego księcia do Polaków, których dręczył, kochając. Chociaż Rymkiewicz nie posługuje się wprost terminologią psychoanalityczną, jego spekulacje na temat psychiki odkrywają struktury analogiczne do Freudowsko-Lacanowskiego modelu perwersji. Konstanty jest rozdwojony, ma jakby dwie osobowości, niczym dr Jeckyll i pan Hyde - co powtarza klasyczny opis rozszczepienia ego perwerta u Freuda ${ }^{39}$. Ma obsesję ładu i porządku, które próbuje narzucić przemocą, identyfikując się z głosem prawa - doprowadzonego jednak do hiperbolicznego absurdu; jest więc też sadystą w sensie, który szkicuje Lacan w eseju Kanta Sadem ${ }^{40}$. Identyfikuje się z zamordowanym ojcem, a jednocześnie łączy z Polakami w nienawiści do babki Katarzyny - a więc realizuje Lacanowski model sadyzmu jako „zwrotu ku ojcu” (père-version), rozwinięty przez Deleuze'a jako przeciwieństwo masochistycznego „zwrotu ku matce”, którą sadysta próbuje usunąć ze swego świata - zwłaszcza gdy jest to potężna „matka falliczna” (jak Katarzyna lub Janion) afirmowana przez masochistę. Podobnie sadystyczny jest Zamoyski w Samuelu Zborowskim, próbując narzucić polskiej szlachcie obcy jej rygoryzm prawa ${ }^{41}$.

Te odległe w czasie eseje łączy nie tylko owa psychopolityczna analogia, lecz także sieć innych subtelnych rezonansów. Samuel Zborowski „przepisuje” dramat Słowackiego. Tymczasem, kreśląc sylwetkę Konstantego, Rymkiewicz sięga po Kordiana i Poema Piasta Dantyszka; wielki książę, choć Rosjanin, często wypowiada się w tekście Rymkiewicza po francusku (podobnie skądinąd

${ }^{37}$ Np. R. Koziołek, Latajacy kret, https://opoka.org.pl/biblioteka/P/PK/tp201326-koziolek.html (d.d. 11.03.2019).

${ }^{38}$ M. Foucault, Przedmowa do transgresji, tłum. T. Komendant, w: Osoby, red. M. Janion, S. Rosiek, Gdańsk 1984, s. 300-321.

${ }^{39}$ D. Matuszek, - Kto ty jesteś? - Mały Hans. Rymkiewicza Freudem, „Teksty Drugie” 2015, nr 2, s. 215, 229.

${ }^{40}$ J. Lacan, Kanta Sadem, tłum. T. Komendant, „Twórczość” 1989, nr 8, s. 38-58.

${ }^{41}$ Prefiguracją prawnego sadyzmu Zamoyskiego jako kasztelana krakowskiego zdaje się u Rymkiewicza Hans Frank z Kinderszenen, charakteryzowany nie tylko jako rządzący podbitym krajem z Wawelu zbrodniarz, lecz i - w osobnym poświęconym temu rozdziale - wybitny prawnik. 
jak Nowosilcow w III części Dziadów), może się więc kojarzyć z inną niedoszłą ofiarą polskiego królobójstwa - Henrykiem Walezym. Ogolona głowa łączy w Samuelu autora z bohaterem; w Wielkim księciu golenie głowy to kara sadysty dla prostytutek i nazbyt porywczego Mochnackiego ${ }^{42}$.

Golenie głowy jako część sadomasochistycznego rytuału seksualnego (Rymkiewicz explicite sugeruje taką interpretacje „,kaźni” prostytutek) i jako własnowolny wyróżnik bezkompromisowego patrioty (sam Rymkiewicz i jego wizja Samuela) to z pozoru - mimo tej samej postaci materialno-zmysłowej - semantycznie zupełnie odmienne znaki. Niedoszłe ogolenie Mochnackiego jakoś je łączy, epizod ten jednak nie znajduje rozwinięcia. Natomiast pisząc Zborowskiego, zainspirowany przez Foucaulta Rymkiewicz mógł już także uwzględniać w fantazmatycznym podtekście swojej narracji te wątki legendy filozofa, które eksponują jego praktyki sadomasochistyczne. Dlaczego jednak miałby je wstecznie skojarzyć z esejem, który powstał, zanim charakter upodobań Foucaulta stał się publicznie wiadomy? Rozważania Janion o de Sadzie i jego francuskiej recepcji mogły się do tego przyczynić, wydają się jednak niewystarczające jako samodzielne źródło ${ }^{43}$.

W grę może wchodzić rezonans z kolejnym korpusem tekstów niejawnie inspirujących eseistykę Rymkiewicza: z twórczością Jerzego Łojka, trzy lata starszego kolegi z Instytutu Badań Literackich, gatunkowo podobną, charakteryzującą się wykraczającymi nieraz poza dyskurs stricte historiograficzny spekulacjami na temat przeszłości - w tym jej wersji alternatywnych. Łojek to autor Szans powstania listopadowego, w oczywisty sposób powiązanych z tematyką Wielkiego księcia (metaforycznie także z Kinderszenen), oraz prac o Konstytucji 3 maja, Stanisławie Auguście i Szczęsnym Potockim, spokrewnionych tematycznie z Wieszaniem i Reytanem. Podobnie jak Rymkiewicz był żarliwym patriotą - w tym samym okresie prześladowanym za działalność opozycyjną - i podobnie jak Rymkiewicza interesował go drugi biegun takiego zaangażowania: zdrada (Potockiego opisuje podobnie jak potem Rymkiewicz Ponińskiego). Choć obaj zasadniczy przedmiot dociekań sytuują na przełomie XVIII i XIX wieku, obaj też czynią motywowane osobistym przeżyciem wycieczki ku paralelnie tragicznym epizodom II wojny światowej: powstaniu warszawskiemu (Rymkiewicz) i zbrodni katyńskiej (Lojek). Łojek skontrapunktował jednak swoje polskie narracje opowieścią o specyficznym wątku kultury francuskiej - zseksualizowanym libertynizmie - w Wieku markiza de Sade ${ }^{44}$.

${ }^{42}$ J. M. Rymkiewicz, Wielki książę..., s. 59-60, 152.

${ }^{43}$ M. Janion, Romantyzm, rewolucja, marksizm. Colloquia gdańskie, Gdańsk 1972, s. 329-332, 351-389.

${ }^{44}$ J. Łojek, Wiek markiza de Sade. Szkice z historii obyczajów i literatury we Francji XVIII wieku, Lublin 1975. 
Przypuszczam, że fantazmat biczowania prostytutek na rozkaz Konstantego wywodzi się - w bardzo konkretnej postaci $-\mathrm{z}$ tego właśnie tomu (Łojek wielokrotnie w całej książce pisze o flagellacji), jej dalszymi powidokami mogą zaś być postać Henryka Walezjusza, który postrzegany był przez polską szlachtę jako psychoseksualnie osobliwy, i kryjąca się za nim inspiracja Foucaultem wraz $\mathrm{z}$ jego legendą queer.

2.

Konstruując narrację o agonie poetyckiego efeba z prekursorem, Harold Bloom explicite powołuje się na Freudowski model edypalny ${ }^{45}$. Model ten zakłada jedność - ojca u Freuda, prekursora u Blooma - nawet jeśli empiryczny materiał konstytuujący fantazmat wywodzi się od kilku postaci; agon musi być pojedynkiem. Relacje Rymkiewicza z poprzednikami trudno tak opisać: rządzi nimi raczej acentryczna sieciowość niż synteza scentralizowanej jedności. Poszczególni mistrzowie i rywale łączą się w tej sieci za pośrednictwem pojedynczych charakterystycznych cech czy osiagnięć - wykładają w Collège de France, golą głowy, mają krzaczaste brwi (jak Konstanty, sam Rymkiewicz i Czesław Miłosz). Jak wspomniałem, po Lacanowsku oznacza to przejście od identyfikacji wyobrażeniowej (jedność wizerunku ciała w lustrze, ego idealne) do symbolicznej (cecha swoista - trait unaire, freudowski einziger Zug jako ideał ego ${ }^{46}$. Efekt jest jednak radykalniejszy niż ten postulowany przez Lacana, który zakłada jedność Wielkiego Innego. Przywodzi raczej na myśl dyskusję z psychoanalizą u Deleuze'a i Guattariego, którzy pojedynczego wilka-ojca chcą zastąpić mnogością watahy, a scentralizowaną drzewiastą strukturę z wyrazistym pniem płaskim i acentrycznym kłączem ${ }^{47}$. Rymkiewiczowska afirmacja rozmaitych form wolnościowego szaleństwa dopełniałaby Deleuzjańskiego ducha, projektując wolnych od edypalnej opresji scentralizowanej władzy Polaków jako schizoli w rozumieniu Anty-Edypa ${ }^{48}$.

Równolegle do słynnej rewizji Freudowskiego przypadku „człowieka od wilków” na początku Tysiąca plateau powstała jednak we francuskiej psychoanalizie konkurencyjna relektura tej klasycznej narracji: Le Verbier de L'homme aux loups Nicolasa Abrahama i Márii Török ${ }^{49}$. Autorzy dekodują sny Pankiejewa jako obrazowe i werbalne symbole sceny pierwotnej, jednak nie tej schematycznie wystandaryzowanej, której szukał Freud, lecz empirycznie konkretnej,

${ }^{45}$ H. Bloom, Leck przed wptywem..., s. 52-55.

${ }^{46}$ Unary trait, http://cahiers.kingston.ac.uk/concepts/unary-trait.html (d.d. 12.03.2019).

${ }^{47}$ G. Deleuze, F. Guattari, Tysiac plateau, red. J. Bednarek, Warszawa 2015, s. 3-45.

${ }^{48}$ G. Deleuze, F. Guattari, Anty-Edyp, tłum. T. Kaszubski, Warszawa 2017.

${ }^{49}$ N. Abraham, M. Torok, The Wolf Man's Magic Word: A Cryptonymy, trans. N. Rand, Minneapolis 1986. 
którą przy tej okazji rekonstruują. Co mogłoby być pisarską sceną pierwotną Rymkiewicza-historycznego eseisty? Odpowiedź jest być może po Freudowsku trywialna: historyczne powieści jego ojca, Władysława Rymkiewicza. Na przykład Romans królewski: Maria Ludwika Gonzaga (włoskiego rodu, ale de facto Francuzka) pragnie (wbrew biernemu oporowi swego męża a polskiego króla, Jana Kazimierza) ustanowić w Rzeczypospolitej silną centralną władzę, przeciwstawioną szlacheckiej „złotej wolności”. Gwarantem jej ciągłości miał być francuski książę na polskim tronie, substytuujący dynastyczne marzenia o dziedzictwie Bizancjum $^{50}$ - a zatem wspólne źródło figur Henryka Walezego i Konstantego Romanowa (już chrzestnym imieniem szykowanego przez babkę Katarzynę na dziedzica Konstantyna Wielkiego, do czego Rymkiewicz-syn kilkakrotnie nawiązuje)... Pierwszoosobowy narrator Romansu jest przy tym protegowanym Jana Andrzeja Morsztyna, poety wielokroć przez Rymkiewicza-syna naśladowanego ${ }^{51}$, sądzony zaś w warszawskim ratuszu i skazany na śmierć (a realnie na banicję) Hieronim Radziejowski zdaje się literackim pierwowzorem Samuela i osądzonych w tymże ratuszu zdrajców z Wieszania.

\section{Bibliografia}

Abraham, Nicolas, Maria Torok, The Wolf Man's Magic Word: A Cryptonymy, trans. N. Rand, Minneapolis 1986.

Bielik-Robson, Agata, Sześć dni stworzenia. Harolda Blooma mitologia twórczości, w: H. Bloom, Lęk przed wptywem. Teoria poezji, tłum. A. Bielik-Robson, M. Szuster, Kraków 2002.

Bloom, Harold, Lęk przed wpływem. Teoria poezji, tłum. A. Bielik-Robson, M. Szuster, Kraków 2002.

Chwin, Stefan, „Trans-Atlantyk” wobec „Pana Tadeusza”, „Pamiętnik Literacki” 1975, nr 4, s. 97-121.

Chwolik, Dominik, Rymkiewicz. Dopowiedzenia, Katowice 2016.

Czajkowska, Agnieszka, Wpływ bez lęku. Jarostaw Marek Rymkiewicz czyta Juliusza Stowackiego, „Wiek XIX. Rocznik Towarzystwa Literackiego im. A. Mickiewicza” 2009, R. 2, s. 160-173.

Delaperrière, Maria, Dialog Miłosza z Mickiewiczem, „Postscriptum Polonistyczne” 2011, nr 1, s. 233-246.

Deleuze, Gilles, Masochism. Coldness and Cruelty, trans. J. McNeill, New York 1989.

Deleuze, Gilles, Félix Guattari, Tysiąc plateau, red. J. Bednarek, przekład zbiorowy, Warszawa 2015.

${ }^{50}$ W. Rymkiewicz, Romans królewski, Łódź 1970.

${ }^{51}$ M. Lisecka, Jan Andrzej Morsztyn w poezji Jarosława Marka Rymkiewicza, http://repozytorium.umk.pl/handle/item/1782 (d.d.11.03.2019). 
Deleuze, Gilles, Félix Guattari, Anty-Edyp, tłum. T. Kaszubski, Warszawa 2017.

Dembińska-Pawelec, Joanna, Jarosław Marek Rymkiewicz w cieniu Miłosza, „Ruch Literacki" 2012, nr 2, s. 209-226.

Dembińska-Pawelec, Joanna, Upiorna wersja tradycji czy romans rodzinny. Rymkiewicz i Bloom - paralela, „Śląskie Studia Polonistyczne” 2013, nr 1, s. 281-295.

Eribon, Didier, Michel Foucault. Biografia, tłum. J. Levin, Warszawa 2005.

Foucault, Michel, Przedmowa do transgresji, thum. T. Komendant, w: Osoby, red. M. Janion, S. Rosiek, Gdańsk 1984, s. 300-321.

Foucault, Michel, Nadzorować i karać, tłum. T. Komendant, Warszawa 1998.

Foucault, Michel, Przedmowa, tłum. T. Komendant, w: M. Foucault, Powiedziane, napisane. Szaleństwo i literatura, Warszawa 1999, s. 5-14.

Gombrowicz, Witold, Dziennik 1961-1969, Kraków 2004.

Halperin, David M., Saint Foucault. Towards a Gay Hagiography, New York 1995.

Janion, Maria, Romantyzm, rewolucja, marksizm. Colloquia gdańskie, Gdańsk 1972.

Janion, Maria, Polska proza cywilna, „Teksty” 1975, nr 2, s. 13-38.

Klein, Melanie, Uwagi na temat niektórych mechanizmów schizoidalnych, tłum. A. Czownicka, w: M. Klein, Pisma, t. 3: Zawiść i wdzięczność, Gdańsk 2007, s. 1-25.

Koziołek, Ryszard, Latajacy kret, https://opoka.org.pl/biblioteka/P/PK/tp201326-koziolek. html (d.d. 11.03.2019).

Kuziak, Michał, „Samuel Zborowski”. Rymkiewicz w zwierciadle Stowackiego, „Ruch Literacki" 2013, nr 4-5, s. 495-516.

Lacan, Jacques, Kanta Sadem, tłum. T. Komendant, „Twórczość” 1989, nr 8, s. 38-58.

Lacan, Jacques, The Ethics of Psychoanalysis 1959-1960, trans. D. Potter, New York 1992.

Lacan, Jacques, Stadium zwierciadła jako czynnik ksztattujacy funkcję Ja, w świetle doświadczenia psychoanalitycznego, tłum. J. W. Aleksandrowicz, „Psychoterapia” 1997, nr 4, s. 5-9.

Lisecka, Małgorzata, Jan Andrzej Morsztyn w poezji Jarosława Marka Rymkiewicza, http://repozytorium.umk.pl/handle/item/1782 (d.d. 11.03.2019).

Łojek, Jerzy, Wiek markiza de Sade. Szkice z historii obyczajów i literatury we Francji XVIII wieku, Lublin 1975.

Marzec, Grzegorz, Hermeneuta i historia. Jarosław Marek Rymkiewicz w Bakecie, Warszawa 2012.

Masiuk, Olga, Mickiewiczowski „tekst życia” w eseistyce Jarosława Marka Rymkiewicza. Lektura biografii romantycznego poety w cyklu „Jak bajeczne żurawie”, Warszawa 2016, https://depotuw.ceon.pl/handle/item/1937 (d.d. 11.03.2019).

Matuszek, Dawid, - Kto ty jesteś? - Mały Hans. Rymkiewicza Freudem, „Teksty Drugie” 2015, nr 2, s. 215-233.

Rymkiewicz, Jarosław Marek, Wieszanie, Warszawa 2007.

Rymkiewicz, Jarosław Marek, Kinderszenen, Warszawa 2008.

Rymkiewicz, Jarosław Marek, Rozmowy polskie w latach 1995-2008, Warszawa 2009.

Rymkiewicz, Jarosław Marek, Samuel Zborowski, Warszawa 2010.

Rymkiewicz, Jarosław Marek, Wielki książę. Z dodaniem rozważań o istocie i przymiotach ducha polskiego, Warszawa 2011. 
Rymkiewicz, Jarosław Marek, Reytan. Upadek Polski, Warszawa 2013.

Rymkiewicz, Władysław, Romans królewski, Łódź 1970.

Skwieciński, Piotr, Ksią̇̇ka na nowe czasy, w: Spór o Rymkiewicza, red. T. Rowiński, Warszawa 2012, s. 154-161.

Sontag, Susan, Choroba jako metafora. AIDS i jego metafory, thum. J. Anders, Warszawa 1999.

Sowa, Jan, Fantomowe ciało króla. Peryferyjne zmagania z nowoczesna forma, Kraków 2011.

Unary trait, http://cahiers.kingston.ac.uk/concepts/unary-trait.html (d.d. 12.03.2019).

Wojda, Dorota, Rewizje historii $i$ dyskursu kryminologicznego: Kuśniewicz, Terlecki, Rymkiewicz, „Przestrzenie Teorii” 2011, nr 15, s. 155-173.

JAN POTKAŃSKI, dr hab., pracownik Zakładu Literatury XX i XXI w. na Wydziale Polonistyki Uniwersytetu Warszawskiego, autor książek: Sobowtór. Różewicz a psychoanaliza Jacquesa Lacana i Melanii Klein (2004), Sens nowoczesnego wiersza. Wersyfikacja Białoszewskiego, Przybosia, Miłosza i Herberta (2004), Parabazy wptywu. Iwaszkiewicz - Bloom - Lacan (2008), Epoka spojrzenia. Literatura i społeczeństwo nowego kapitalizmu (2014), Wolność realnego. Kant, Hegel i Deleuze a literatura polska (2018). 